\title{
Lukasz Piętak
}

Uniwersytet Łódzki

\section{TEORIA BIEGUNÓW WZROSTU FRANÇOIS PERROUX I IMPLEMENTACJA JEJ ZALOŻEŃ W HISZPANII W LATACH 1964-1975}

Streszczenie: Praca stanowi analizę koncepcji biegunów wzrostu, opracowanej przez wybitnego francuskiego profesora François Perroux. W pierwszej części artykułu autor przedstawia filozoficzną i metodologiczną analizę koncepcji Perroux. Druga część poświęcona jest analizie implementacji biegunów wzrostu w Hiszpanii w latach 1964-1975. Oryginalność koncepcji Perroux polega na wprowadzeniu do rozważań pojęcia przestrzeni ekonomicznej oraz pominięciu znaczenia przestrzeni fizycznej. $Z$ drugiej strony koncepcja Perroux jest uogólnieniem metod stosowanych już dużo wcześniej przez innych ekonomistów. Teoria bieguna wzrostu Perroux jest częścią teorii wzrostu zharmonizowanego, ale wzrost zharmonizowany nie jest tożsamy z koncepcją wzrostu harmonijnego, rozumianego jako istnienie naturalnych harmonii w życiu ekonomicznym. Perroux wskazuje na konieczność stałego harmonizowania istniejących sił ekonomicznych dla dobra ogólnego. Perroux jest przekonany o niezrównoważonym charakterze wzrostu gospodarczego, nie tylko przestrzennie, ale także sektorowo. Ta opinia nie jest czymś nowym. Po prostu wpisuje się on do grupy badaczy ekonomii przekonanych o niezrównoważonym wzroście gospodarczym. Jednak Perroux, w przeciwieństwie do innych, nie ogranicza się jedynie do stwierdzenia faktów. Stara się wytłumaczyć, dlaczego tak jest. W tym celu stworzył teorię, która tłumaczy fenomen niezrównoważonego wzrostu gospodarczego. Jest przekonany, że wzrost gospodarczy pojawia się w punktach z różną częstotliwością i w różnym czasie. Perroux wskazuje na kompleksy przemysłowe oraz całe gałęzie przemysłu mogące być źródłem wzrostu gospodarczego i nazywa je biegunami wzrostu.

Polityka biegunów wzrostu była bardzo popularna w latach 60 i 70 . Wiele krajów, jak Francja, Hiszpania, Grecja czy Włochy, wykorzystywało bieguny w planach gospodarczych. Ta tendencja została pohamowana na skutek kryzysu naftowego w 1973 r. Wówczas aktywna polityka państwa w planowaniu gospodarczym zaczęła ustępować miejsca liberalizmowi gospodarczemu.

W przypadku Hiszpanii polityka biegunów wzrostu polegała na pobudzaniu tworzenia przemysłu w regionach dających nadzieję na przyspieszoną industrializację. Podczas kolejnych trzech okresów planistycznych stworzono bieguny umiejscowione w różnych regionach. W tamtym czasie w Hiszpanii istniał problem migracji w kierunku regionów bogatych, jak: Katalonia, Madryt czy Kraj Basków. Zatem implementacja biegunów miała nie tylko wpłynąć na rozwój przemysłu, ale także powstrzymać proces migracji.

Jednym ze sposobów oceny funkcjonowania biegunów w hiszpańskiej gospodarce jest zbadanie liczby powstałych przedsiębiorstw, poziomu produkcji oraz stopy wzrostu gospodarczego uzyskanej w regionach z biegunami, salda wymiany handlowej pomiędzy regionem $\mathrm{z}$ biegunem i regionami go otaczającymi. Autor wykorzystał metodę polegającą na porówna- 
niu dwóch okresów: pierwszego okresu bez funkcjonujących biegunów oraz drugiego z biegunami. Analiza także porównuje otrzymane rezultaty ze średnią krajową.

Weryfikacja teorii bieguna wzrostu na przykładzie Hiszpanii pokazuje, że ten rodzaj prowadzonej polityki regionalnej przegrał rywalizację z procesem migracji ludności w kierunku regionów uprzemysłowionych kraju. Ponadto okres istnienia hiszpańskich biegunów był za krótki, aby uzyskać zaplanowane rezultaty. Badania wskazały na brak korelacji pomiędzy istnieniem biegunów i uzyskiwanymi rezultatami. Istniały regiony, gdzie bieguny wpływały na przyspieszony wzrost wskaźników, ale w tym samym czasie inne regiony z biegunami uzyskiwały wskaźniki malejące.

Słowa kluczowe: wzrost gospodarczy, teoria biegunów wzrostu, polityka regionalna.

DOI: 10.15611/e21.2014.1.11

\section{Wstęp}

W latach sześćdziesiątych XX wieku w teorii ekonomii pojawiła się tendencja do łączenia komponentów makroekonomicznych z mikroekonomicznymi (por. [Solow 1956; Snowdon i in. 1998, s. 51-56]). W zakresie gospodarki regionalnej miało to wyraz w postaci zbliżenia teorii rozwoju regionalnego z teorią lokalizacji przemysłu. Teoria biegunów wzrostu François Perroux jest właśnie przykładem podejmowanych zabiegów. Wpływ przedsiębiorstwa lub kompleksu przemysłowego na wzrost gospodarczy w danej przestrzeni ekonomicznej w pełni oddaje próby integracji mikroekonomii z makroekonomią.

Celem artykułu jest przybliżenie koncepcji biegunów wzrostu oraz zbadanie rezultatów ich funkcjonowania w Hiszpanii. Przeprowadzone badania opierają się zarówno na statystykach dotyczących prowincji hiszpańskich, jak i na szerokiej literaturze obcojęzycznej. Autor dokonuje analizy wpływu poszczególnych biegunów na poziom wzrostu gospodarczego, rozwój przemysłu, migrację ludności czy też na wymianę handlową. Równocześnie zestawia otrzymane rezultaty z okresem przedbiegunowym oraz $\mathrm{z}$ danymi opisującymi dynamikę poszczególnych wskaźników w wymiarze krajowym.

O popularności biegunów może świadczyć fakt ich implementacji w wielu krajach, takich jak Włochy, Francja, Hiszpania czy Brazylia. Bieguny wzrostu stanowiły podstawowe narzędzie wykorzystywane przez politykę regionalną wymienionych państw. Zakładano, że powstanie nowoczesnych kompleksów przemysłowych charakteryzujących się ponadprzeciętną dynamiką wzrostu gospodarczego wpłynie na pobudzenie aktywności ekonomicznej w całym regionie oraz powstrzyma migrację ludności z regionów biednych w kierunku regionów bogatych. Podobne cele biegunom wzrostu postawiono w Hiszpanii. Z jednej strony miały pobudzić aktywność przemysłową regionów problemowych, $\mathrm{z}$ drugiej powstrzymać migrację ludności w kierunku północno-wschodnim kraju, do takich regionów jak: Katalonia, Kraj Basków czy Nawarra. 


\section{Założenia koncepcji}

Koncepcja biegunów wzrostu i na niej oparta teoria lokalizacji są szeroko analizowane $\mathrm{w}$ literaturze ekonomicznej. Po raz pierwszy pojęcia pôle de croissance Perroux użył w 1955 r. [1955a], później modyfikował teoretyczne założenia związane z biegunem wzrostu [Perroux 1961]. Jednak oprócz Perroux także inni ekonomiści, przeważnie reprezentujący francuską i belgijską szkołę ekonomii, wnieśli znaczący wkład naukowy do zagadnienia, tj.: L. Davin, J. Paelinck. F. Lajugie czy J.R. Boudeville. Ich prace są uzupełnieniem idei Perroux na temat zjawiska polaryzacji i biegunów wzrostu.

Teoria Perroux opiera się na trzech założeniach oraz specyficznej koncepcji przestrzeni ekonomicznej, zwanej banalna (l'espace banal). Te cztery elementy, czyli trzy punkty wyjścia, traktowane jako oczywiste, oraz koncepcja przestrzeni ekonomicznej stanowią podstawę bieguna wzrostu pôle de croissance.

Po pierwsze, Perroux zakłada istnienie nierównowagi sektorowej i przestrzennej towarzyszącej wzrostowi gospodarczemu. Według Perroux, jeśli podda się analizie przykłady wzrostu gospodarczego, można przyjąć za pewnik jego niezrównoważony charakter. W dziele $L$ 'Économie $d u X X^{e}$ siècle odpowiednie fragmenty potwierdzają jego opinię o takim charakterze wzrostu gospodarczego [Perroux 1964, s. 143, 258, 264]. Zatem Perroux nie należy do grona ekonomistów przekonanych o zrównoważonym charakterze wzrostu gospodarczego (por. [Cassels 1927; Nurkse 1953; Lewis 1955; Rosenstein-Rodan 1943]). Wpisuje się do grona badaczy przekonanych o niezrównoważonym jego charakterze [por. Milhau 1956 ; Gannagé 1962 ; Béguin 1963; Nicholls 1961]. Jeśli gospodarka wzrasta, to tempo tego procesu nie jest jednakowe we wszystkich sektorach, a tym bardziej nie pojawia się w tym samym czasie. Wzrost gospodarczy objawia się w różnych gałęziach gospodarki z różną intensywnością. Niektóre z nich mogą rozwijać się bardzo dynamicznie i zarazem stać się motorem wzrostu dla całej gospodarki. Podobnie sytuacja wygląda w ujęciu przestrzennym. Pojawiający się wzrost gospodarczy w danym regionie musi prowadzić do jego niezrównoważonego charakteru względem innym regionów ${ }^{1}$ :

«La croissance n'apparaît pas partout à la fois; elle se manifeste en des points ou pôles de croissance, avec des intensités variables«

(Wzrost gospodarczy nie pojawia się wszędzie jednocześnie. Pojawia się w punktach lub biegunach wzrostu, z różną intensywnością) [Perroux 1964, s. 143].

Drugim elementem koncepcji biegunów wzrostu jest przekonanie Perroux o istnieniu w gospodarkach krajowych kompleksów przemysłowych dominujących nad resztą gałęzi gospodarki. Oddziałują one na inne sektory, wpływają na ewolucję

${ }^{1}$ Jak zauważa T. Hermansen, Perroux rozwinął teorię biegunów wzrostu w poszukiwaniu wyjaśnienia, dlaczego wzrost gospodarczy nie jest zgodny ze stacjonarną teorią wzrostu zrównoważonego G. Casselsa [Hermansen 1977, s. 32]. 
strukturalną gospodarki narodowej oraz na zwiększenie dynamiki wzrostu gospodarczego. Ponadto charakteryzują się zdolnością do wpływania na poziom cen, zysków oraz rozwoju technologicznego. Dzięki swojej sile oddziaływania na inne sektory gospodarki uzyskują pozycję dominującą, wpływając jednocześnie na dynamikę wzrostu gospodarczego. Przykładem wskazującym na dominację kompleksu przemysłowego, nie tylko w kraju, ale także w Europie, mogło być Zagłębie Rury, w którym w 1950 r. wydobywano 20\% europejskiego węgla [Perroux 1955b].

Trzecim elementem uznawanym za punkt wyjścia w teorii Perroux jest idea J. Schumpetera o innowacjach. Według Perroux, innowacje stanowią podstawową przyczynę występowania różnic strukturalnych w systemie produkcyjnym. Pojawienie się nowych innowacyjnych gałęzi przemysłu wpływa na przyspieszoną dynamikę wzrostu gospodarczego. Przemysły innowacyjne zaczynają charakteryzować się jego zwiększoną dynamiką w porównaniu z innymi sektorami, które stają się coraz starsze, a ich produkcja z czasem jest zastępowana przez substytuty.

Ostatnim elementem teorii biegunów wzrostu jest koncepcja przestrzeni ekonomicznej. Jeśli spojrzymy na listę ekonomistów zajmujących się problemem lokalizacji, to Perroux znajduje się pośród znaczących nazwisk. Jego zainteresowanie lokalizacją wynikało z lektury literatury niemieckiej, bo właśnie ekonomiści z tego kraju są najbardziej znani w tym obszarze badań. Na potwierdzenie tego faktu można przytoczyć słowa C. Clarka, twierdzącego, że ekonomia przestrzenna zawsze była specjalnością niemiecką [Clark 1964, s. 7]. Jednak większość ekonomistów niemieckich i anglosaskich przykładała szczególną wagę do czynnika miejsca. Przypisywała mu charakter geograficzny - przestrzeń jako powierzchnia, determinowana przez odległość. Perroux proponuje jednak poszerzenie rozważań na temat lokalizacji o przestrzeń abstrakcyjną, opracowaną przez nowoczesną matematykę i fizykę. W miejsce przestrzeni o charakterze pasywnym: region, kraj, Perroux proponuje wykorzystanie koncepcji przestrzeni topologicznej:

«Nous restons obsédés par l'espace banal et la localisation banale» (Jesteśmy splątani przez przestrzeń banalną i lokalizację banalną) [Perroux, 1964, s. 132].

Według Perroux, przestrzeń w sensie terytorialnym i geograficznym ustanawiają granice, warunkujące i jednocześnie zakłamujące występowanie sił ekonomicznych. Zdaniem francuskiego ekonomisty istnieje tyle przestrzeni, ile jest zbiorów abstrakcyjnych relacji, nieprzypisanych do konkretnego miejsca. Perroux wprowadza rozróżnienie pomiędzy przestrzenią geonomiczną i przestrzenią ekonomiczną. Proponuje, aby zrezygnować z używania określenia przestrzeń geonomiczna, ponieważ jest to słowo rzadko używane, i zastąpić je pojęciem przestrzeni banalnej [Perroux 1964, s. 127]. Przestrzeń banalna według Perroux jest definiowana przez relacje pomiędzy punktami, liniami, powierzchniami, ludźmi i grupami ludzi, rzeczami i grupami rzeczy. Jednak Perroux podkreśla, że jego zainteresowanie będzie się skupiać na przestrzeni w sensie ekonomicznym, definiowanej przez relacje pomiędzy elementami ekonomicznymi [Perroux 1964, s. 127]. Według Perroux, można wyróżnić trzy rodzaje przestrzeni ekonomicznej: 
1. Przestrzeń ekonomiczna jako zawartość planu (L'espace économique comme contenu d'un plan).

W przypadku przedsiębiorstwa produkcyjnego plan jest rozumiany jako zbiór istniejących relacji pomiędzy przedsiębiorstwem a jego kooperantami, dostarczającymi do niego surowce, półfabrykaty, siłę roboczą oraz kapitał, ale także ostatecznymi konsumentami. Te powiązania uciekają podporządkowaniu kartograficznemu. Relacje definiowane jako plan przedsiębiorstwa nie podlegają ograniczeniom terytorialnym oraz zmieniają się w czasie [Perroux 1964, s. 130].

2. Przestrzeń jako pole sił (L'espace économique comme champ de forces).

$\mathrm{Z}$ tego punktu widzenia przedsiębiorstwo znajduje się $\mathrm{w}$ centrum abstrakcyjnej przestrzeni, zdefiniowanej przez Perroux jako „pole sił” (champ de forces). Wówczas przestrzeń ekonomiczna jest zbudowana $\mathrm{z}$ centrów lub biegunów, emanujących siłami odśrodkowymi, do których zarazem trafiają siły dośrodkowe. Bieguny przeciągają do siebie ludzi i rzeczy, ale zarazem też je odpychają. Przyciągają także inne zjawiska ekonomiczne, chociażby takie jak popyt i podaż. Te zbiory relacji są determinowane przez zasięg wpływów każdego bieguna. Jednak obszar jego oddziaływania podlega dynamicznym zmianom nierejestrowanym przez kartografię. Perroux jako przykład podaje francuskie przedsiębiorstwo Michelin. Można przypisać je do zdeterminowanego obszaru w sensie geograficznym, natomiast w sensie ekonomicznym obszar wpływów tej znanej fabryki „ucieka” zapisom kartografii [Perroux 1964, s. 131].

3. Przestrzeń jako zbiór homogeniczny (L'espace économique comme ensemble homogène).

Ostatnia koncepcja przestrzeni jest mniej użyteczna niż dwie pierwsze koncepcje. Według niej, przedsiębiorstwo ma pewną strukturę, bardziej lub mniej homogeniczną wobec innych przedsiębiorstw działających w danej przestrzeni ekonomicznej. Jednostka produkcyjna należy do pewnego obszaru, gdzie obowiązuje pewien poziom cen. Wszystkie przedsiębiorstwa ustalają je na podobnym poziomie, pomimo zróżnicowania w systemie produkcji, wielkości sprzedaży czy ponoszonych kosztów. Perroux pisze:

«Ces firmes sont dans le même espaces économique, quelles que soient leurs coordonnées dans l'espace banal».

(Te przedsiębiorstwa znajdują się w tej samej przestrzeni ekonomicznej, niezależnie od tego, jakie mają położenie w przestrzeni banalnej) [Perroux 1964, s. 144].

Podsumowując rozważania Perroux na temat rodzajów przestrzeni ekonomicznej, należy podkreślić, że przestrzeń rozumiana jako pole sił jest koncepcją najbardziej pasującą do definicji bieguna wzrostu pôle de croissance. Jej abstrakcyjny charakter wpisuje się w koncepcję bieguna i opisuje jego działanie o charakterze polaryzacyjnym. 
Chociaż pojęcie bieguna wzrostu jest najbardziej rozpowszechnione pośród innych koncepcji wypracowanych przez Perroux, to zakresowo najszerszym pojęciem jest punkt rozwoju - point de développement, obejmujący swoim zakresem bieguny rozwoju - pôle de développement, sfery rozwoju-zones de développement oraz osie rozwoju - axes de développement.

«Les points de développement: il englobe les pôles de développement (unités simples ou complexes), les zones de développement et les axes de développement».

(Punkty rozwoju: obejmują bieguny rozwoju (jednostki proste i złożone), strefy rozwoju i osie rozwoju) [Perroux 1964, s. 256].

Perroux wprawdzie wprowadza kolejne pojęcia jeszcze bardziej komplikujące zrozumienie jego koncepcji, jednak ich nie definiuje. Za powstawanie wspomnianych zones odpowiedzialne są jednostki napędowe, wywołujące efekt aglomeracji, skupiające wokół siebie czynniki produkcji. Posługując się przykładem hipotetycznego bieguna produkującego węgiel i stal, Perroux wskazuje na możliwości stworzenia jednostki o wielkim zasięgu oddziaływania, zdolnej redukować koszty działalności gospodarczej. Jednak w tym przypadku jest niekonsekwentny w stosunku do rozumienia przestrzeni. Chociaż odcina się od jej geograficznego charakteru, nazywając ją banalna, to jednak w tym fragmencie wprowadza pojęcie obszaru zones, powiązanego z geograficznym wymiarem przestrzeni. To kolejna niekonsekwencja w koncepcji Perroux, którą należy mieć na uwadze.

W przypadku pojęcia osi rozwoju - axes de développement, Perroux nie zawęża go jedynie do aspektu transportu, tylko raczej do relacji pomiędzy jednostkami produkującymi dobra komplementarne [Perroux 1964, s. 182]. Nie można także go utożsamiać z osiami transportowymi, wykorzystywanymi przez J.H. Thünena czy A. Webera. Niemieccy badacze rozwijali swoje teorie, opierając się na założeniu przestrzeni fizycznej, geograficznej, gdzie odległość miała priorytetowe znaczenie dla rentowności produkcji. Natomiast dla Perroux najważniejsza jest przestrzeń operacyjna, uciekająca od kartografii. Perroux wprowadza jeszcze pojęcie ogniska rozwoju foyer de progres. Jednak i tutaj brakuje precyzyjnej definicji. Z tekstu można wywnioskować, że jest to miejsce „promieniowania” na inne regiony [Perroux 1964].

Publikacja L'Économie du $X X^{e}$ siècle jest zbiorem artykułów stworzonych przez Perroux w różnych okresach - wraz z upływem czasu zmieniał się także pogląd autora na biegun wzrostu. O ile w 1955 r. pisze tylko o przemysłach napędowych - motrice, o tyle już w 1961 r. mówi nie tylko o przemysłach napędowych, ale i firmach napędowych - firme motrice. Wprowadza również pojęcia przemysłu kluczowego - industrie -clé, jak również kompleksu przemysłowego - complexes industriels. W 1955 r. Perroux przemysł napędowy zdefiniował jako autonomiczną jednostkę umiejscowioną w przestrzeni ekonomicznej, charakteryzującą się takimi cechami, jak innowacyjność i impulsowość. Wokół niej zgromadzone są inne jednostki ekonomiczne, a ich lokalizacja jest konsekwencją istnienia właśnie przemysłu 
napędowego. Perroux w tym przypadku odnosi się do nowoczesnych przemysłów, charakteryzujących się wielką koncentracją kapitałów, wykorzystujących technikę w mechanizacji produkcji, przemysłów mających w danym okresie ponadprzeciętną stopę wzrostu dochodu [Perroux 1964, s. 144].

Od różnorodności terminologicznej ważniejsze jest jednak to, co tak naprawdę oznaczają pojęcia „przemysł napędowy” oraz „firma napędowa”. Mają one znaczenie relatywne i odnoszą się do poziomu uzyskiwanej produkcji. Wyrażają ponadprzeciętny poziom wzrostu oraz siłę dominacji, czyli pociągania innych jednostek gospodarczych, funkcjonujących w danej przestrzeni ekonomicznej. Zatem najodpowiedniejszym tłumaczeniem pojęcia „napędowy” przemysł czy firma są jednostki produkcyjne trudniące się działalnością zaliczaną do branży nowoczesnej, technicznie zaawansowanej, z ponadprzeciętnym poziomem elastyczności popytowo-dochodowej, a jednocześnie promującym innowacje w środowisku oddziaływania. Taka jednostka napędowa może w pewnym momencie wpływać pobudzająco na otoczenie, ale również powodować efekty odwrotne, przyczyniając się do stagnacji lub recesji w danej przestrzeni ekonomicznej.

Zatem biegunem wzrostu może być, oczywiście mając na uwadze abstrakcyjność pojęcia pôle de croissance, firma napędowa, kompleks przemysłowy, aglomeracja miejska, ale także region, kraj czy też międzynarodowa organizacja gospodarcza. Obszerny wachlarz możliwości oddziaływania bieguna wzrostu w wymiarze przestrzennym nie jest sprzeczny z założeniami teoretycznymi, wypracowanymi przez Perroux. Gdy przestrzeń jest rozumiana jako terytorium planu i dotyczy danego państwa, wówczas analizowanym regionem będzie państwo. Podobnie sytuacja będzie wyglądać w przypadku grupy państw czy organizacji ponadnarodowych.

Według Perroux, jednostka napędowa unité motrice jest biegunem wzrostu, jeżeli wpływa na modyfikację struktur organizacyjnych innych jednostek, zmianę ich metody zarządzania oraz przyspieszony wzrost gospodarczy [Perroux 1964, s. 167169]. Zdaniem Perroux jednostka napędowa może zostać utworzona przez [Perroux 1964, s. 238]:

a) jedno przedsiębiorstwo,

b) grupę przedsiębiorstw zinstytucjonalizowanych (przedsiębiorstw publicznych lub półpublicznych),

c) grupę przedsiębiorstw niezinstytucjonalizowanych, których działalność może być produkcyjna lub w rzadszych przypadkach rolnicza.

Jednostka napędowa może być zlokalizowana w danym regionie, jeśli surowce wykorzystywane do produkcji uzyskuje właśnie z tego terenu. Należy mieć także na uwadze istnienie możliwości całkowitej lub częściowej delokalizacji jednostki napędowej. Taka sytuacja będzie mieć miejsce wtedy, gdy w wymianie surowców oraz dóbr będą uczestniczyć inne regiony lub kraje. Tym, co charakteryzuje rolę jednostki napędowej, jest fakt wzbudzania sił dośrodkowych i odśrodkowych, skierowanych w kierunku przedsiębiorstw znajdujących się w tym samym regionie i na obszarach przyległych. Oczywiście siła polaryzacji każdego bieguna jest różna i zależy od za- 
sięgu oddziaływania. Według Perroux, każdy biegun w swoim otoczeniu oddziałuje na kilku płaszczyznach [Perroux 1964, s. 239]:

a) przez poziom ceny i realizowane przepływy,

b) przez uzyskanie dominacji pośród innych firm funkcjonujących na rynku,

c) przez wpływ na poziom realizowanej konsumpcji przez gospodarstwa domowe i przedsiębiorstwa,

d) przez przyczynianie się do wzrostu, rozwoju i postępu gospodarczego.

Podobną koncepcję bieguna wzrostu do koncepcji Perroux przedstawia J. Friedman. Według Friedmana, warunkiem istnienia bieguna wzrostu jest występowanie przemysłu podstawowego, charakteryzującego się ponadprzeciętną stopą wzrostu. Funkcjonowanie takiego przemysłu gwarantuje powstanie kompleksu przemysłowego, składającego się z przedsiębiorstw kooperujących w ramach przemysłu podstawowego. Suma aktywności ekonomicznej związanej z istnieniem kompleksu przemysłowego jest biegunem wzrostu.

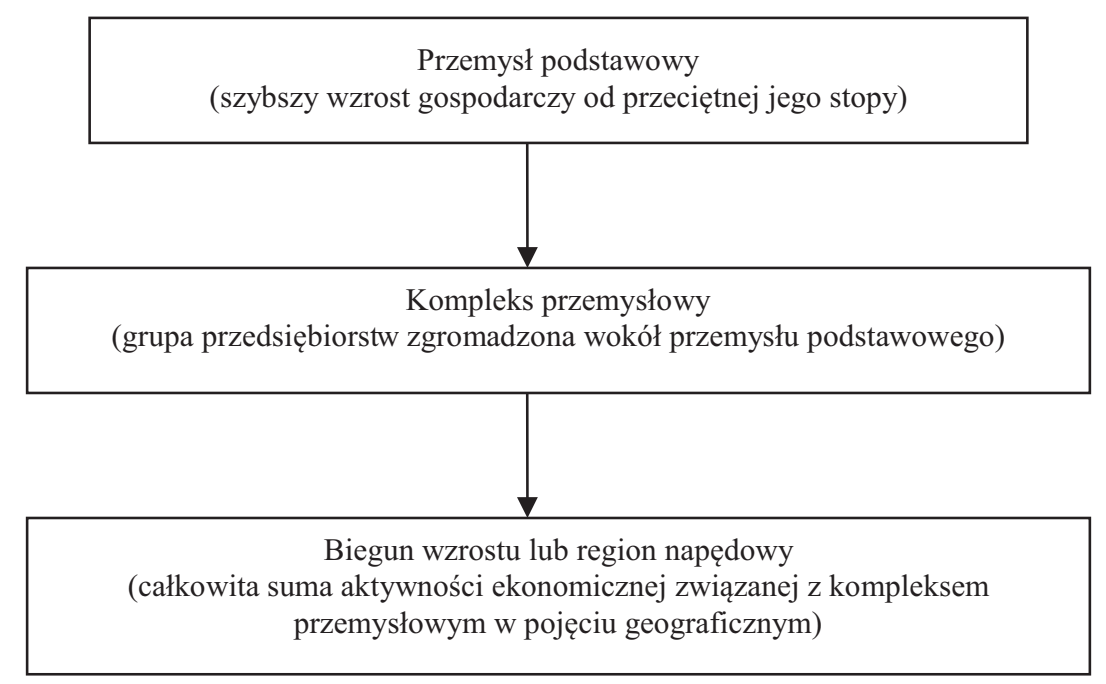

Rys. 1. Struktura bieguna wzrostu według J. Friedmanna

Źródło: [Friedmann 1973, s. 33].

Perroux, aby wythumaczyć oddziaływanie bieguna wzrostu, buduje kolejne modele opisujące sytuację w obszarze zamkniętym i otwartym w długim i krótkim okresie [Perroux 1964, s. 181-184]. Dla potrzeb analizy wykorzystuje tablicę przepływów międzygałęziowych W. Leontiefa, przekształconą w ten sposób, aby spełniała warunki analiz wewnątrzregionalnych oraz międzyregionalnych.

Jak zauważa Ł. Czuma, W. Isard przed Perroux wprowadził do teorii lokalizacji koncepcję Leontiefa. Dalej Czuma wskazuje na różnice między stanowiskiem Isarda i Perroux. Ten pierwszy leontiefowską analizę wykorzystuje w jej oryginalnej po- 
staci, natomiast Perroux w celu wyjaśnienia własnych założeń przekształca analizę Leontiefa. Isard akceptuje podział tabeli Leontiefa według podstawowych sektorów: rolnictwo, górnictwo, przemysł. Z kolei Perroux wykorzystuje tablicę dla wyjaśnienia działalności firm napędowych i napędzanych [Czuma 1973, s. 38].

Tabela 1. Tablica przepływów międzygałęziowych według F. Perroux

\begin{tabular}{|c|c|c|c|c|c|c|}
\hline \multirow[b]{3}{*}{ Input } & \multicolumn{6}{|c|}{ Output } \\
\hline & \multicolumn{2}{|c|}{ A } & \multicolumn{3}{|c|}{ B } & \multirow{2}{*}{ 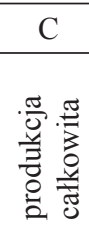 } \\
\hline & 营 & 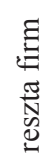 & 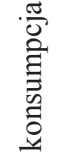 & 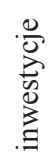 & 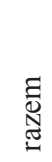 & \\
\hline A: Firma napędowa... & 0 & 30 & 22 & 8 & 30 & 60 \\
\hline Reszta firm... & 23 & 0 & 15 & 2 & 17 & 40 \\
\hline B: Wartość dodana.... & 37 & 10 & & & 47 & \\
\hline C: Produkcja całkowita.... & 60 & 40 & & & & 100 \\
\hline
\end{tabular}

Źródło: [Perroux 1964, s. 197].

Perroux zakłada dominującą rolę bieguna wzrostu w danym obszarze. Określa także wielkość rynku opanowaną przez jednostkę napędową. Jest to $60 \%$ wszystkich zakupów i wytworzonych towarów z danego obszaru [Perroux 1964, s. 179]. Pozostałe $40 \%$ rynku opanowane jest przez przedsiębiorstwa przemysłowe lub o charakterze rolniczym, konkurujące ze sobą na zasadach wolnego rynku. Model ten odzwierciedla sytuację, kiedy życie gospodarcze danego regionu zależy od jednej jednostki napędowej - bieguna wzrostu. Jednak bierze pod uwagę tylko istnienie firm monopolistycznych oraz duopolistycznych. Zatem dla Perroux biegunem wzrostu, a zarazem głównym czynnikiem powodującym wzrost gospodarczy, są właśnie tego rodzaju przedsiębiorstwa. Ponadto Perroux dzieli kraje na dwa rodzaje. Jedne $\mathrm{z}$ nich tworzą grupę krajów ognisk - nations foyers, te drugie zaś grupę państw podporządkowanych - nations affiliées. Kraje dominujące-ogniska wywierają dominujący wpływ na kraje afiliowane. Kraje podporządkowane można poznać po wielkości obrotów handlowych z krajem ogniskiem. Poziom ten to $30 \%$ lub więcej handlu zagranicznego kraju afiliowanego. Taka sytuacja decyduje o podporządkowaniu kraju afiliowanego wobec kraju ogniska. Ma to wyraz w warunkach wymiany handlowej terms of trade, przepływach kapitałów czy mobilności czynników produkcji [Perroux 1964, s. 186]. Jak twierdzi Perroux, sytuacja dla narodów podporządkowanych jest trudna, ponieważ są one uzależnione od krajów ognisk i zdane na ich łaskę. Oczywiście istnieje pewna szansa na zmniejszenie różnic w poziomie rozwoju gospodarczego przez modernizację gospodarek krajów podporządkowanych czy zwiększenie ich konkurencyjności. Lecz pogodzenie interesów kraju-ogniska z krajem afiliowanym jest niemożliwe [Perroux 1964, s. 187]. 
W latach pięćdziesiątych i sześćdziesiątych ekonomiści francuscy i belgijscy zrealizowali wiele prac na temat biegunów wzrostu i ich wpływu w zdeterminowanym obszarze. Można je podzielić na dwie grupy: prace o charakterze opisowym i prace zorientowane na proces planowania. Do pierwszej grupy należą: [Perroux 1955b; Bauchet, 1955; Derwa 1957; Czuma 1973]. Do drugiej grupy należą: [Boudeville 1957; Davin 1959; Rosenfeld 1964].

Według Czumy, teoria regionalnego rozwoju uwzględniającego bieguny wzrostu stanowi fragment systemu teoretycznego - teorii wzrostu zharmonizowanego. Dalej Czuma podkreśla, że teoria Perroux jest uogólnieniem stosowanej już praktyki. Wcześniej J. Paelinck zaproponował cztery etapy historyczne rozwoju biegunów wzrostu [Czuma 1973, s. 49].

Podstawowym zarzutem wobec koncepcji Perroux jest jej abstrakcyjny i ogólny charakter. W związku z tym sama koncepcja bieguna wzrostu jest niejasna i nie do końca dopracowana. Jak stwierdził N. Hansen, idea bieguna wzrostu staje się koncepcją złożoną z innych subkoncepcji, dość niejasnych i swobodnie ze sobą powiązanych [Hansen 1967, s. 723]. Paelnick, Boudeville, Friedman, odnosząc się w swoich publikacjach do problemu biegunów wzrostu, nie ukrywali jego niejasnego charakteru [Paelinck 1965; Boudeville 1966; Friedman 1972]. Hansen podkreślał, że koncepcie i wyrażenia stworzone przez Perroux wymagają bardziej precyzyjnego zdefiniowania, a ich forma powinna być bardziej jasna i spójna [Hansen 1967, s. 723-724]. Natomiast J. Paelinck stwierdził, że «koncepcja bieguna wzrostu była bardzo często źle rozumiana» i mylona z narodzinami przemysłów kluczowych czy też bazy produkcyjnej [Paelinck 1965, s. 9-11]. Było to wynikiem braku precyzji, z jaką Perroux ogłaszał swoje nowe koncepcje w artykułach publikowanych w końcu dekady lat pięćdziesiątych i w latach sześćdziesiątych. Złe rozumienie koncepcji pôle de croissance wynikało z faktu przypisywania jej w pewnym stopniu znaczenia „magicznego". Miała ona bowiem stanowić antidotum na określone problemy ekonomiczne. Ponadto, według J.R. Lasuén, teoria bieguna wzrostu nie jest w stanie odpowiedzieć na podstawowe pytania: dlaczego, gdzie, jak i kiedy powstają i rozwijają się bieguny wzrostu? [Lasuén 1976, s. 264].

Jak pisze Czuma, koncepcja bieguna wzrostu nabrała decydującego znaczenia we francuskiej i włoskiej polityce regionalnej [Czuma 1973, s. 32]. Dalej Czuma przytacza wypowiedź J.R. Boudeville'a:

«Z praktycznego punktu widzenia francuska polityka regionalna opiera się przede wszystkim na regionie spolaryzowanym i biegunach rozwoju» [Czuma 1973, s. 32].

Oprócz Włoch i Francji koncepcję pôle de croissancie wcielały w życie także inne państwa. Politykę gospodarczą opierały na niej takie kraje, jak Hiszpania, podczas trzech planów rozwoju, Niemcy, Czechosłowacja, Wenezuela, Brazylia, a także Grecja.

Z punktu widzenia relacji występujących pomiędzy poszczególnymi sektorami $\mathrm{i}$ ich wpływem na wzrost gospodarczy to praca W. Isarda jest najbardziej powiązana 
z ideą biegunów wzrostu Perroux [Isard 1960]. Według Isarda, kompleks produkcyjny może zostać zdefiniowany jako całokształt działalności gospodarczej realizowanej zdeterminowanej przestrzeni. Tutaj pojawiają się znaczące różnice pomiędzy dwoma ekonomistami. Dla Perroux biegun wzrostu ma przede wszystkim znaczenie funkcjonalne i jest terytorialnie zdelokalizowany. W przypadku Isarda kompleks przemysłowy jest zlokalizowany geograficznie. Ponadto Isard stara się zdefiniować możliwie wszystkie istniejące relacje pomiędzy przemysłami w zdeterminowanej przestrzeni geograficznej oraz wskazuje na możliwości płynące $\mathrm{z}$ ich istnienia.

Kolejną różnicą pomiędzy Perroux a Isardem jest cel opracowania naukowego. Perroux stara się stworzyć teorię thumaczącą powstawanie wzrostu gospodarczego. Pozwala mu na to eksponowanie koncepcji o charakterze abstrakcyjnym. Z kolei celem Isarda jest przedstawienie ważności relacji technologicznych i ekonomicznych występujących wokół różnych sektorów. Znajomość tych relacji pozwala na ustalenie najefektywniejszej strategii wzrostu dla danego zdeterminowanego obszaru.

$\mathrm{Z}$ podobną sytuacją mamy do czynienia, porównując teorię rozwoju regionalnego Perroux z koncepcją Hirschmana. Czuma takie zabiegi nazywa nieporozumieniem. Według Czumy, Hirschman zajmował się problemem wzrostu gospodarczego w skali całego narodu i nawet daleko idąca interpretacja tekstów Hirschmana nie upoważnia do wniosków, jakoby brał on pod uwagę niezrównoważony rozwój gospodarczy regionów. Nie wykorzystuje on pojęcia przestrzeni operacyjnej, a dopiero to umożliwiałoby Hirschmanowi elastyczne traktowanie pojęcia regionu [Czuma 1973, s. 48].

Teoria biegunów wzrostu przekracza granice wyznaczane przez przestrzeń geograficzną, bazującą na punktach, liniach czy odległościach. Stwarza także nowe możliwości wytłumaczenia niezrównoważonego charakteru wzrostu gospodarczego. Wyjaśnia dominującą rolę, jaką w procesie wzrastania gospodarki odgrywają jednostki produkcyjne, pojedyncze lub działające w grupie. Teoria biegunów wzrostu podkreśla wagę innowacji, dzięki którym jednostki napędowe osiągają ponadprzeciętny poziom produkcji i produktywności oraz stanowią siłę napędową dla innych sektorów gospodarki. Ponadto teoria biegunów wzrostu stanowi próbę wyjaśnienia fenomenu wzrostu gospodarczego na poziomie sektorowym. Punktem wyjścia teorii jest stwierdzenie, że wzrost gospodarczy zawsze związany jest z powstawaniem braku równowagi, efektem pociągania oraz asymetriami o charakterze strukturalnym.

\subsection{Polityka biegunów w Hiszpanii w latach 1964-1975}

W latach sześćdziesiątych dwudziestego wieku w Hiszpanii zainicjowano nowy etap w gospodarowaniu krajem. Rządy hiszpańskie wzorowały się na Francji, gdzie proces planowania gospodarczego opierał się na biegunach wzrostu (por. [Hansen 1968]). Zatem i w Hiszpanii bieguny stały się podstawowym narzędziem planowania rozwoju kraju. Jak zauważa H.W. Richardson, planowanie oparte na biegunach wzrostu okazało się bardzo „atrakcyjne”, ponieważ stwarzało możliwości integra- 
cji polityki przemysłowej z polityką planowania przestrzennego [Richardson 1986, s. 129]. Funkcjonowanie biegunów w gospodarce hiszpańskiej zostało zapoczątkowane przez I Plan Rozwoju Ekonomiczno-Społecznego („El Primer Plan de Desarrollo Económico y Social"), obejmujący cztery lata - od 1964 do 1967 r. włącznie. I Plan zakładał stworzenie biegunów rozwoju polos de desarrollo oraz biegunów promocji polos de promoción. Bieguny rozwoju zaplanowano w miejscach, gdzie istniał już przemysł, jednak na niższym poziomie niż w innych centrach przemysłowych kraju, z niskim poziomem dochodu, z dużym udziałem rolnictwa w wytwarzaniu ogółu dochodu oraz ze znacznym poziomem emigracji. Natomiast bieguny promocji umiejscowiono w regionach niemających przemysłu, ale dysponujących zasobami ludzkimi i naturalnymi, dającymi nadzieję na przemianę, przy udziale państwa, w obszary przemysłowe [Rodríguez Saiz i in. 1986, s. 187].

W okresie obowiązywania I Planu stworzono siedem biegunów. Pięć z nich: La Coruña, Sevilla, Valladolid, Vigo oraz Zaragoza było biegunami rozwoju, dwa zaś: Burgos i Huelva, biegunami promocji. Okres funkcjonowania bieguna przewidziano na pięć lat z możliwością przedłużenia ${ }^{2}$. Po zgłoszeniu kandydatury i wygraniu konkursu przemysły inwestujące w obszarach funkcjonowania biegunów mogły liczyć na wiele ułatwień i ulg, jak: [Rodríguez Saiz i in. 1986, s. 187].

1. Subwencje w wysokości $20 \%$ inwestycji realizowanych w obrębie bieguna promocji oraz $10 \% \mathrm{w}$ obrębie bieguna wzrostu.

2. Dowolność w sposobie naliczania amortyzacji w ciągu pierwszych pięciu lat realizacji inwestycji.

3. Przyspieszony proces wywłaszczania z terenów realizacji inwestycji.

4. Redukcja do $95 \%$ podatków państwowych i lokalnych.

Ponadto przemysły decydujące się na inwestowanie w obrębie wyznaczonego bieguna mogły skorzystać z preferencyjnie oprocentowanego kredytu udzielanego na dziewięć lat [Alonso Santos 2000, s. 109-133].

$\mathrm{Na}$ inne korzyści wskazuje L. Rodríguez Saiz. W jego opinii, bieguny Burgos i Valladolid, umiejscowione w regionie Castilla y León, znajdowały się na korzystnej osi, łączącej bogatą, uprzemysłowioną Północ ze stolicą kraju Madrytem. Galicyjskie bieguny La Coruña i Vigo mogły w przyszłości znajdować się na we-

\footnotetext{
${ }^{2}$ Biegun Burgos powołany na mocy Dekretu 153/1964 z dnia 30 stycznia jako biegun promocji przewidziany był na pięć lat. Na mocy dekretu 240/1969 z 21 listopada przedłużono jego istnienie do roku 1974, przekształcając go jednocześnie w biegun rozwoju. Biegun Huelva powołano na mocy Dekretu 153/1964 z 31 stycznia 1964 r. jako biegun promocji, jego funkcjonowanie zostało przedłużone do roku 1974, z przekształceniem go jednocześnie w biegun rozwoju. Biegun La Coruña został powołany do życia Dekretem 153/1964 z dnia 30 stycznia. Dekret 240/1969 przedłużył jego funkcjonowanie do grudnia roku 1971. Bieguny Sevilla i Valladolid powołano Dekretem 153/1964 z dnia 30 stycznia jako bieguny rozwoju, a ich istnienie zostało przedłużone do grudnia roku 1970. Biegun Vigo początkowo powołano do życia na pięć lat Dekretem 153/1964, później jego funkcjonowanie zostało przedłużone do roku 1971. W przypadku bieguna Zaragoza jego funkcjonowanie nie zostało przedłużone po upływie pięciu lat i wygasło w roku 1969.
} 
wnętrznych osiach komunikacyjnych tego regionu. Zaragoza położona w regionie Aragonia znajdowała się w centrum trójkąta Madryt-Barcelona-Bilbao. Natomiast bieguny Huleva i Sevilla wraz z obszarem Gibraltaru mogły stanowić trójkąt przemysłowy i stać się motorem rozwoju dla całego regionu Andaluzji [Rodríguez Saiz i in. 1986, s. 188].

W celu uzyskania dotacji i subwencji inwestorzy musieli spełnić wiele wymagań. Na początku działalności w obszarze bieguna inwestorów zobligowano ich do stworzenia dwudziestu miejsc pracy i zainwestowania trzech milionów peset. W późniejszym okresie funkcjonowania biegunów wymagana liczba nowych miejsc pracy wzrastała do stu, a wielkość zainwestowanego kapitału do czterdziestu milionów peset.

Dewaluacja pesety w listopadzie 1967 r. wymusiła przedłużenie obowiązywania I Planu do roku 1969. Wówczas wszedł w życie kolejny plan pod nazwą: II Plan Rozwoju Ekonomiczno-Społecznego 1969-1971 (,Segundo Plan de Desarrollo Económico y Social"). W obszarze polityki regionalnej głównym narzędziem jej oddziaływania pozostały bieguny wzrostu i promocji.

W latach 1972-1975 obowiązywał III Plan Rozwoju Ekonomiczno-Społecznego, przyjęty w maju $1972 \mathrm{r}$. W swoich założeniach był ambitniejszy niż dwa poprzednie plany zakładające roczny 6-procentowy wzrost dochodu narodowego. Przewidywał on bowiem średnioroczny wzrost dochodu narodowego na poziomie 7\% [Requeijo González 2005, s. 34]. Plan zakładał również rezygnację z polityki biegunów na rzecz wielkich obszarów ekspansji przemysłowej gran área de expansión industrial [Richardson 1976, s. 53]. Wprowadzał także koncepcję osi rozwoju ejes de desarrollo.

Najpowszechniejszą formą oceny funkcjonowania biegunów jest oszacowanie liczby przedsiębiorstw stworzonych $\mathrm{w}$ ich obrębie, wielkości zrealizowanych inwestycji oraz liczby zatrudnionych w nowo powstałych przedsiębiorstwach. Uzupełniające informacje dotyczą wpływu biegunów na poziom wytwarzanego dochodu oraz zatrudnienia. Tabele 2 i 3 przedstawiają dane dotyczące biegunów w Hiszpanii w latach 1964-1975. Pierwsza z nich dotyczy długości ich funkcjonowania, druga zaś liczby istniejących przedsiębiorstw w obrębie danego bieguna, poziomu zrealizowanych inwestycji, liczby stworzonych miejsc pracy oraz wskaźnika zrealizowanych inwestycji w stosunku do miejsc pracy. W przypadku biegunów powołanych do życia z dniem 1 stycznia 1964 r. trzy z nich: Huelva, La Coruña oraz Burgos, wykazywały wysoki poziom wskaźnika relacji wielkości inwestycji na zatrudnionego, odpowiednio: 5,58, 2,74 oraz 1,42 . W pozostałych biegunach poziom ten nie przekraczał miliona peset. W zakresie stworzonych miejsc pracy na wyróżnienie zasługują bieguny: Valladolid i Vigo oraz Burgos, gdzie inwestycje realizowane pozwoliły na stworzenie odpowiednio 19,5 tys., 15,3 tys. oraz 10 tys. miejsc pracy.

W przypadku biegunów powstałych w ramach II i III Planu, czyli od roku 1970 (tab. 2), na wyróżnienie zasługuje wysoki poziom wskaźnika realizowanych inwestycji na zatrudnionego. Jedynie w biegunie Villagarcía de Arosa wskaźnik ten kształtował się na poziomie 0,85 , czyli poniżej miliona peset na pracującego. Po- 
Tabela 2. Bieguny w Hiszpanii oraz okres ich funkcjonowania

\begin{tabular}{|l|l|l|}
\hline \multicolumn{1}{|c|}{ Biegun } & $\begin{array}{c}\text { Data rozpoczęcia } \\
\text { funkcjonowania }\end{array}$ & $\begin{array}{c}\text { Data zakończenia } \\
\text { funkcjonowania }\end{array}$ \\
\hline Burgos & 1 stycznia 1964 & 31 grudnia 1973 \\
\hline Huelva & 1 stycznia 1964 & 31 grudnia 1973 \\
\hline La Coruña & 1 stycznia 1964 & 31 grudnia 1971 \\
\hline Vigo & 1 stycznia 1964 & 31 grudnia 1971 \\
\hline Sevilla & 1 stycznia 1964 & 31 grudnia 1970 \\
\hline Valladolid & 1 stycznia 1964 & 31 grudnia 1970 \\
\hline Zaragoza & 1 stycznia 1964 & 31 grudnia 1969 \\
\hline Granada & 1 stycznia 1970 & 31 grudnia 1979 \\
\hline Córdoba & 1 stycznia 1971 & 31 grudnia 1980 \\
\hline Oviedo & 1 stycznia 1971 & 31 grudnia 1982 \\
\hline Logrońo & 1 stycznia 1972 & 31 grudnia 1981 \\
\hline Villagarcía de Arosa & 1 stycznia 1972 & 31 grudnia 1981 \\
\hline
\end{tabular}

Źródło: [Richardson 1976, s. 147].

Tabela 3. Rezultaty funkcjonowania biegunów podczas realizacji trzech planów rozwoju (1964-1975)

\begin{tabular}{|l|c|c|c|c|}
\hline Biegun & $\begin{array}{c}\text { Liczba } \\
\text { funkcjonujących } \\
\text { przedsiębiorstw }\end{array}$ & $\begin{array}{c}\text { Zrealizowane } \\
\text { inwestycje } \\
\text { (miliony peset) }\end{array}$ & $\begin{array}{c}\text { Liczba } \\
\text { stworzonych } \\
\text { miejsc pracy }\end{array}$ & $\begin{array}{c}\text { Inwestycje/ } \\
\text { stworzone miejsca } \\
\text { pracy }\end{array}$ \\
\hline Burgos & 151 & $14.532,8$ & 10.222 & 1,42 \\
\hline Huelva & 68 & $33.290,4$ & 5.965 & 5,58 \\
\hline La Coruña & 46 & $11.319,9$ & 4.126 & 2,74 \\
\hline Vigo & 76 & $9.476,5$ & 15.264 & 0,62 \\
\hline Sevilla & 74 & $9.206,2$ & 9.644 & 0,95 \\
\hline Valladolid & 68 & $18.843,9$ & 19.527 & 0,96 \\
\hline Zaragoza & 110 & $6.559,3$ & 8.241 & 0,79 \\
\hline Granada & 9 & $2.588,0$ & 670 & 3,86 \\
\hline Córdoba & 9 & $4.105,9$ & 855 & 4,80 \\
\hline Oviedo & 63 & $20.961,1$ & 3.424 & 6,04 \\
\hline Logrońo & 17 & $3.027,7$ & 1.085 & 2,79 \\
\hline Villagarcía de Arosa & 9 & $1.243,1$ & 1.457 & 0,85 \\
\hline Razem & 700 & $135.154,8$ & 80.480 & 1,68 \\
\hline
\end{tabular}

Źródło: [Rodríguez Saiz i in. 1986, s. 199].

nadto biegun Oviedo, pomimo pięcioletniego okresu funkcjonowania, zajmował drugie miejsce pod względem zrealizowanych inwestycji. Tylko w biegunie Huelva ten poziom był wyższy i wyniósł 33,2 mld peset. Podsumowując, należy stwierdzić, 
że funkcjonowanie biegunów w Hiszpanii w latach 1964-1975 przyczyniło się do powstania 700 przedsiębiorstw, stworzenia ponad 80 tys. miejsc pracy, poziom zaś zrealizowanych inwestycji osiągną 135 mld peset.

Uzupełniającą informacją związaną z istnieniem biegunów jest ich wpływ na poziom wytwarzanego dochodu oraz produkcji przemysłowej. Tabela 4 przedstawia zestawienie stopy wzrostu dochodu i produkcji przemysłowej w prowincjach posiadających biegun w dwóch okresach: 1955-1964 oraz 1964-1975. W latach 1955-1964 bieguny nie istniały, natomiast okres 1964-1975 to czas ich funkcjonowania. Zatem porównanie dwóch kolumn tabeli pozwala odpowiedzieć na pytanie o skuteczność istnienia biegunów. Ponadto współczynnik większy od jednego oznacza stopę wzrostu wyższą od krajowej, w przypadku zaś niższej stopy wzrostu od średniej krajowej współczynnik przybiera wartość poniżej jedności. W zależności od rodzaju wykorzystanych danych mogą wypływać różne wnioski. Jeżeli za podstawę efektywności biegunów przyjmie się stopę wzrostu wytwarzanego dochodu, to pozytywnymi przykładami są bieguny umiejscowione w Andaluzji, a mianowicie Huelva i Sevilla oraz La Coruña, Zaragoza, Córdoba i Oviedo. W przypadku biegunów: Vigo, Burgos, Valladolid oraz Granada, ich istnienie nie przyczyniło się do zwiększenia dynamiki wzrostu dochodu. Wprost przeciwnie, zanotowały jego spadek. Gdy jednak za wyznacznik efektywności przyjmiemy stopę wzrostu produkcji przemysłowej, wówczas wnioski są inne. Na przykład biegun Burgos notujący obniżkę wskaźnika stopy wytwarzanego dochodu uzyskał pozytywny rezultat w przypadku produkcji przemysłowej. I odwrotnie, Córdoba notująca wzrost stopy wytwarzanego dochodu

Tabela 4. Stopa wzrostu dochodu i produkcji przemysłowej w prowincjach mających biegun w Hiszpanii w latach 1955-1973

\begin{tabular}{|l|c|c|c|c|c|c|}
\hline \multirow{2}{*}{ Biegun } & $1955-1964$ & $1964-1973$ & & $1955-1964$ & $1964-1973$ & \\
\cline { 2 - 3 } \cline { 5 - 6 } & $\begin{array}{c}\text { wytworzony } \\
\text { dochód - } \\
\text { wskaźnik }\end{array}$ & $\begin{array}{c}\text { wytworzony } \\
\text { dochód - } \\
\text { wskaźnik }\end{array}$ & Rezultat & $\begin{array}{c}\text { produkcja } \\
\text { przemysłowa - } \\
\text { wskaźnik }\end{array}$ & $\begin{array}{c}\text { produkcja } \\
\text { przemysłowa - } \\
\text { wskaźnik }\end{array}$ & Rezultat \\
\hline Burgos & 0,923 & 0,781 & - & 0,922 & 1,153 & + \\
\hline Huelva & 0,763 & 1,174 & + & 0,873 & 1,390 & + \\
\hline La Coruña & 0,862 & 1,021 & + & 1,014 & 1,078 & + \\
\hline Vigo & 1,075 & 1,017 & - & 1,440 & 1,229 & - \\
\hline Sevilla & 0,696 & 0,935 & + & 0,630 & 0,835 & + \\
\hline Valladolid & 1,078 & 0,956 & - & 1,637 & 1,157 & - \\
\hline Zaragoza & 0,901 & 1,000 & + & 0,803 & 1,099 & + \\
\hline Granada & 1,018 & 0,932 & - & 0,979 & 0,933 & - \\
\hline Córdoba & 0,781 & 0,853 & + & 0,883 & 0,695 & - \\
\hline Oviedo & 0,801 & 0,973 & + & 0,792 & 1,034 & + \\
\hline Hiszpania & 1,000 & 1,000 & & 1,000 & 1,00 & \\
\hline
\end{tabular}

Źródło: opracowanie na podstawie: [Rodríguez Saiz i in. 1986, s. 204, 206]. 
w okresie istnienia bieguna w przypadku produkcji przemysłowej była prowincją z obniżką poziomu produkcji przemysłowej.

Tabela 5 zawiera dane dotyczące realizowanych projektów w ramach polityki biegunów oraz wyodrębnia przemysły dominujące. W większości biegunów przeważa specjalizacja przemysłowa. Wyjątek stanowią bieguny La Coruña i Sevilla, gdzie wyraźna jest dominacja sektora chemicznego. Ponadto w każdym z biegunów można wyodrębnić przemysł dominujący. W przypadku Vigo i Burgos jest to wytwarzanie produktów metalowych, w Valladolid produktów chemicznych oraz mechanicznych, Córdoba charakteryzowała się produkcją spożywczą, w Sevilli zaś największy udział stanowiła produkcja materiałów budowlanych. Warta podkreślenia jest rozpiętość w liczbie projektów zaakceptowanych i realizowanych. W przypadku pierwszych biegunów jedynym wytłumaczeniem może być przedłużający się okres powstawania zaakceptowanej już inwestycji. Ponadto pomimo akceptacji nie udało się zrealizować wszystkich inwestycji. Część z nich po prostu porzucono.

Tabela 5. Sektory dominujące w biegunach w Hiszpanii w 1973 r.

\begin{tabular}{|c|c|c|c|}
\hline Biegun & $\begin{array}{c}\text { Projekty } \\
\text { zaakceptowane }\end{array}$ & $\begin{array}{l}\text { Projekty } \\
\text { realizowane }\end{array}$ & $\begin{array}{c}\text { Procentowy udział sektora dominującego } \\
\text { w realizowanych inwestycjach }\end{array}$ \\
\hline Burgos & 182 & 154 & Produkty metalowe (30) \\
\hline Huelva & 90 & 59 & Produkcja bardzo zróżnicowana \\
\hline La Coruña & 85 & 44 & Przemysł chemiczny (59) \\
\hline Sevilla & 106 & 78 & $\begin{array}{l}\text { Materiały budowlane, szkło, ceramika, } \\
\text { produkty metalowe i chemiczne ( } 53 \text { ) }\end{array}$ \\
\hline Valladolid & 89 & 73 & $\begin{array}{l}\text { Produkty metalowe, mechaniczne (41), } \\
\text { chemiczne (35) }\end{array}$ \\
\hline Vigo & 114 & 81 & $\begin{array}{l}\text { Produkty metalowe, mechaniczne (53), } \\
\text { materiały budowlane, szkło, ceramika } \\
\text { (20) }\end{array}$ \\
\hline Zaragoza & 137 & 123 & $\begin{array}{l}\text { Produkty metalowe, papierowe } \\
\text { i chemiczne }\end{array}$ \\
\hline Granada & 27 & 3 & ------------------------------------------- \\
\hline Córdoba & 36 & 2 & Przemysł spożywczy (30) \\
\hline Oviedo & 92 & 3 & $\begin{array}{l}\text { Minerały, metale podstawowe, produkty } \\
\text { metalowe }\end{array}$ \\
\hline Logrońo & 36 & 1 & --------------------------------------------- \\
\hline $\begin{array}{l}\text { Villagarcía de } \\
\text { Arosa }\end{array}$ & 24 & 0 & ------------------------------------------ \\
\hline Razem & 1.018 & 621 & \\
\hline
\end{tabular}

Źródło: [Richardson 1976, s. 154]. 
Teoria biegunów wzrostu François Perroux i implementacja jej założeń w Hiszpanii...

Tabela 6. Geograficzny podział sprzedaży i zakupów biegunów w Hiszpanii w 1971 r.

\begin{tabular}{|l|c|c|c|c|c|c|}
\hline \multirow{2}{*}{ Biegun } & \multicolumn{6}{c|}{ Sprzedaż (\%) } \\
\cline { 2 - 7 } & $\begin{array}{c}\text { suma } \\
\text { (mln. pts.) }\end{array}$ & $\begin{array}{c}\text { sam } \\
\text { biegun }\end{array}$ & $\begin{array}{c}\text { reszta } \\
\text { prowincji }\end{array}$ & $\begin{array}{c}\text { najbliższe } \\
\text { prowincje wokół } \\
\text { bieguna }\end{array}$ & $\begin{array}{c}\text { reszta } \\
\text { Hiszpanii }\end{array}$ & zagranica \\
\hline Huelva & 16,823 & 16,7 & 5,2 & 5,4 & 64,3 & 8,4 \\
\hline Sevilla & 11,123 & 2,5 & 27,3 & 3,0 & 57,5 & 9,7 \\
\hline La Coruña & 12,859 & 4,5 & 15,1 & 3,2 & 70,8 & 6,4 \\
\hline Vigo & 10,760 & 2,6 & 23,5 & 2,5 & 58,7 & 12,7 \\
\hline Burgos & 15,833 & 0,2 & 6,6 & 3,0 & 78,3 & 11,9 \\
\hline Valladolid & 15,410 & 12,5 & 4,5 & 0,8 & 81,7 & 0,5 \\
\hline Zaragoza & 9,579 & 2,6 & 18,1 & ----- & 68,7 & 10,8 \\
\hline & & & & & & \\
\hline Huelva & 13,321 & 22,7 & 27,9 & 2,3 & 9,2 & 37,9 \\
\hline Sevilla & 7,208 & 3,9 & 44,3 & 1,0 & 30,5 & 20,3 \\
\hline La Coruña & 9,271 & 6,3 & 15,3 & 1,2 & 9,3 & 67,9 \\
\hline Vigo & 6,030 & 2,4 & 29,1 & 5,4 & 58,7 & 4,4 \\
\hline Burgos & 12,031 & 0,3 & 16,5 & 4,2 & 67,9 & 11,1 \\
\hline Valladolid & 12,813 & 16,0 & 12,5 & 0,6 & 69,4 & 1,5 \\
\hline Zaragoza & 6,461 & 3,8 & 33,1 & ------- & 59,2 & 3,9 \\
\hline
\end{tabular}

Źródło: [Richardson 1976, s. 157].

Tabela 6 dotyczy geograficznego podziału wymiany handlowej biegunów powołanych do życia przez I Plan. Zawarte w niej dane wskazują na ich silne powiązania eksportowe z innymi regionami Hiszpanii. Na przykład biegun Valladolid sprzedawał $81,7 \%$ wytworzonej produkcji regionom hiszpańskim. Ponadto udział biegunów w handlu zagranicznym był niewielki, a bilans handlowy w większości przypadków zamykał się ujemnym saldem. Jedynie biegun Vigo osiągnął dodatnie saldo wymiany międzynarodowej. Kolejne dwa bieguny, Burgos i Valladolid, także zamykają handel zagraniczny z saldem ujemnym, jednak jest ono stosunkowo niewielkie. Ponadto wymiana handlowa wewnątrz biegunów także była niewielka. Wyjątek stanowią Huelva i Valladolid, gdzie sprzedaż realizowana w obrębie bieguna wynosiła odpowiednio $16,7 \%$ oraz $12,5 \%$, a w przypadku zakupów $22,7 \%$ oraz 16,0\%. Jak zauważa Richardson, wysoka importochłonność biegunów Huleva i La Coruña wynikała z uzależnieniu tych prowincji od surowców, takich jak ropa naftowa czy aluminium [Richardson 1976, s. 156]. 


\section{Podsumowanie}

Polityka biegunów wzrostu funkcjonowała w Hiszpanii przez trzy kolejne okresy planistyczne. Gdyby o jej skuteczności miał świadczyć okres ich istnienia, to można by uznać, że jej rezultaty były niezadowalające. III Plan zaniechał polityki biegunów i nie przewidywał powstawania nowych. J. Cuadrado Roura w artykule poświęconym teorii bieguna wzrostu zadaje pytanie o przełożeniu teorii na stosowaną praktykę i o to, czy czasem nie jest to „skok w pustkę”. De la teoria a la praxis: ¿un salto en el vacio? (Od teorii do praktyki: skok w pustkę?). Co prawda nie dokonuje on analizy funkcjonowania biegunów w poszczególnych krajach, ale w jego przekonaniu relacja pomiędzy teorią a praktyką jest bardzo słaba [Cuadrado Roura 1977, s. 129-166].

Z kolei Richardson, analizujący funkcjonowanie biegunów w Hiszpanii, wskazuje na zbyt pochopną, jego zdaniem, rezygnację z polityki biegunów. W jego ocenie za szybko oczekiwano pozytywnych rezultatów, a okres dziesięciu lat był na to za krótki. Dwadzieścia lub dwadzieścia pięć lat pozwoliłoby dopiero ocenić skuteczność biegunów. Ponadto Richardson uważa, że funkcjonowanie biegunów nie zdołało zaspokoić oczekiwań z nimi związanych, ponieważ były one za wysokie. W osiągnięciu sukcesu w polityce biegunów przeszkodziła także etyka prowadzenia polityki ekonomicznej państwa, dążąca do ograniczania udziału władz centralnych W życiu gospodarczym, a to stało w sprzeczności z funkcjonowaniem biegunów. Richardson wskazuje także na brak rozbudowy infrastruktury technicznej w biegunach, przede wszystkim budownictwa mieszkaniowego, ponadto podkreśla niski poziom kapitału zagranicznego przyciąganego przez bieguny w okresie funkcjonowania [Richardson 1976, s. 164-171]. Natomiast Czuma, analizując istnienie biegunów w południowych regionach Włoch, wskazuje na nie do końca trafne zrozumienie funkcjonowania bieguna rozwoju w teorii Perroux [Czuma 1973, s. 77]. Z podobną sytuacją mamy do czynienia w przypadku Hiszpanii. Implementacja polityki biegunów wpłynęła na stworzenie wielu zakładów, jednak ich zasięg nie odpowiadał wielkości jednostki napędowej, zdolnej wygenerować ponadprzeciętny wzrost gospodarczy w obszarze funkcjonowania bieguna. Ponadto sam udział poszczególnych biegunów w wymianie handlowej z prowincjami sąsiednimi był niewielki. Powstałe bieguny przegrały „rywalizację” z naturalnymi biegunami, ulokowanymi w północno-wschodniej części kraju. Ich istnienie nie było w stanie powstrzymać masowej migracji ludności w kierunku wielkich centrów przemysłowych, jak Madryt, Katalonia czy Kraj Basków.

\section{Literatura}

Alonso Santos J.L., Las políticas de industrialización y su impacto en el desarrollo de las regiones en España, „Boletín del Instituto de Geografía” 2000, no. 42. 
Bauchet P., Les tableau économiques. Analyse de la région Lorraine, Edition Génin, Librairie de Médicis, Paris 1955.

Béguin H., Aspects géographiques de la polarisation, „Tiers Monde” 1963, t. 4, no. 16.

Boudeville J.R. Contribution à l'étude des poles croissance brésiliens: Une industrie motrice - la sidérurgie du Minas Gerias, 'Cahiers de l'I.S.E.A.', Paris 1957, série F, no.10.

Boudeville J.R. , Problems of Regional Economic Planning, Edinburgh University Press, Edinburgh 1966.

Cassels G., Thoretiche Sozialöconomie, Leipzing 1927.

Clark C., Localizzazione industrialne e popolazione, Mediolan 1964.

Cuadrado Roura J.R. , El contenido de la teoría de los polos de crecimiento en su concepción original, „Cuadernos de Ciencias Económicas y Empresariales”, Malaga, 1977, no.1.

Czuma Ł., Francois Perroux teoria wzrostu zharmonizowanego a rozwój gospodarczy poludniowych Włoch, KUL, Lublin 1973.

Davin L.E., Deeger L., Paelinck J., Dynamique économique de la région Liégeoise, Presses Universitaries de France, Paris 1959.

Derwa L., Analyse input-output de la région Liégeoise, 'Revue du Conseil économique Wallon', september-november 1957.

Friedmann J., La estrategia de los polos de crecimiento como instrumento de la política de desarrollo, [in:] F. Perroux, J. Friedmann y J. Tinbergen, Los polos de desarrollo y la planificación nacional, urbana y regional, Nueva Visión, Buenos Aires, Argentina 1973.

Friedmann J., A General Theory of Polarized Development, [w:] N.M. Hansen (ed.), Growth Centers in Regional Economic Development, Free Press, New York 1972.

Gannagé E., Économie du Développment, Presses Universitaries de France, Paris 1962.

Development Pole Theory in a Regional Context, Kyklos, 20, 1967.

Hansen N.M., French Regional Planning, Indiana University Press, Bloomington 1968.

Hansen N.M.(ed.), Growth Centers in Regional Economic Development, Free Press, New York 1972.

Hermansen T., Polos y centros de desarrollo en el desarrollo nacional y regional. Elementos de un marco teóretico, [in:] A.R. Kukliński (ed.), Polos y centros de crecimiento en la planificación regional, México 1977. Wersja angielskojęzyczna: Growth Poles and Growth Centres in Regional Planning, Holandia 1972.

Isard W., Methods of Regional Analysis: an Introduction to Regional Science, M. I.T. Press, New York 1960.

Lasuén J.R., Ensayos sobre economía regional y urbana, Ariel, Barcelona 1976.

Lewis W.A., The Theory of Economics Growth, III: Irvin, Homewood 1955.

Milhau J., La théorie de la croissance et l'expansion régionale, „Revue de L'Économie Appliquée”, Jullet-septembre, tome 9, 1956.

Nicholls W.H., Industrialization factor markets and agricultural development, "Journal of Political Economy", Chicago 1961, no. 69(4).

Nurkse R., Problems of Capital Formation in Underdeveloped Countries, Oxford University Press, New York 1953.

Paelinck J., La teorie du developpement regional polarisé, 'Cahiers de l'I.S.E.A', Paris 1965, no.15, série L.

Perroux F., Note sur la nation de pôle de criossance, „Ekonomie Appliquée ” 1955a, no. 1 i 2.

Perroux F., Materiaux pour une analyse de la croissancie economique, „Cahiers de l'I.S.E.A.”, série D - Le Revenu national, fascicule I, 1955b, no. 8.

Perroux F., La firme motrice dans la région et la région motrice. En Teorie et Politique de l'Expansión Regionale, Actes du colleque international de l'Institut de science économique de l'Université de Liége, Bruxelles 1961.

Perroux F., L'Économie du XX $X^{e}$ siècle, Paris 1964. 
Requeijo González J., La era del quantum: 1960-1974, 'ICE', 2005, no. 826.

Richardson H.W., Economía regional y urbana, Alianza Editorial, Madryt, wersja oryginału: Regional and Urban Economics, 1986.

Richardson H.W., Politica y planificación del desarrollo regional en España, Alianza Editorial, Madrid 1976.

Rodríguez Saiz L., Martín Pliego J., Parejo Gámir J., Almoguera Gómez A., Política económica regional, Alianza Editorial, Madryt 1986.

Rosenfeld R., Structure et perspective économiques de la Province de Turin, „Metra 3 ”1964, no. 4.

Rosenstein-Rodan P., Problems of industrialization of Eastern and South-Eastern Europe, "Economic Journal" 1943, vol. 53, Issue 210/211.

Snowdon B.H. Vane, Dynarczyk P., Wspótczesne nurty teorii makroekonomii, PWN, Warszawa 1998.

Solow R.M., A contribution to the theory of economic growth, "The Quarterly Journal of Economics", 1956, no. 70 .

Tamames R., Rueda A., Estructura económica de España, 25 edición, Alianza Editorial, Madryt 2008.

\section{THE GROWTH POLES THEORY BY FRANÇOIS PERROUX AND THE IMPLEMENTATION OF ITS ASSUMPTIONS IN SPAIN IN THE YEARS OF 1964-1975}

Summary: This paper is devoted to the analysis of the concept of growth poles theory elaborated by an outstanding French professor François Perroux. In the first part the author presents philosophical and methodological analysis of Perroux's concepts. The second part is devoted to the analysis of the implementation of the growth poles theory in Spain in the years 1964-1975.

The originality of Perroux's concept lies in the introduction of economic space in a consideration and the omission of the role played by physical space. On the other hand, Perroux's concept is the generalization of the method applied much earlier by other economists. Perroux's growth poles theory is the part of theory of harmonized growth, but harmonized growth is not the concept of harmonious growth understood as the natural harmony existing in the economic life. Perroux indicates the need for permanent harmonizing of economic forces for social welfare. Perroux is convinced the economic growth is unsustainable, not only spatially but also by sector. That opinion was not something new. He simply belongs to a group of researchers of economics convinced of unsustainable growth. However, there is one difference. Perroux, not like the others, limits only to establish the fact. He tries to explain why that is. Therefore, he created the theory which explained the phenomenon of unsustainable economic growth. He believes the economic growth appears at the points with different frequencies and at different time. Perroux also points to the industrial complexes and entire industries that can be a source of economic growth which he calls "growth poles".

Growth poles policy was very popular in the 60s and 70s. Many countries like France, Spain, Greece or Italian had poles in their economic plans. This tendency was halted as a result of the oil crisis in 1973. Then the active policy of the state in economic planning began to give the way to economic liberalism.

In case of Spain, the growth poles policy consisted in the stimulation of industry formation in regions which give hope for accelerated industrial development. During three consecutive periods of planning in Spain a number of poles situated in different regions were created. At that time in Spain there was a problem of migration towards rich regions like Catalonia, 
Madrid or Basque Country. Therefore, the aim of the implementation of the poles was not only to develop the industry, but also to stop the migration process.

One way to evaluate the functioning of the poles in the Spanish economy is examining the amount of established companies, the level of production and the rate of economic growth obtained in regions with poles, the balance of trade between a region with the pole and surrounding regions. The method used by the author consists in comparing two periods: the first period without the pole and the second period with the pole. The analysis also compares the results obtained with the national average.

The verification of growth poles theory in Spanish case shows that regional planning policy lost the competition with the migration process towards the industrialized regions of the country and the period of existing Spanish poles was too short to obtain the planned results. There was no correlation between the existence of the pole and the achieved indicators. There were regions where the poles affected the growth of indicators, but at the same time other regions with the pole had descending indicators.

Keywords: economic growth, growth poles theory, regional policy. 